ISSN 1997-5902

\title{
Indigenous fungal entomopathogens associated with the oil palm leaf miner Coelaenomenodera lameensis Berti and Mariau in Ghana
}

\author{
Boafo' ${ }^{1}$. A., Eziah ${ }^{2}$ V. Y and Yawson² G. K. \\ ${ }^{1}$ African Regional Postgraduate Program in Insect Science (ARPPIS)., P. O. Box LG 59 Legon. University Of Ghana \\ Legon . E-mail: yolttie@gmail.com \\ *2Department of Crop Science, College of Agriculture and Consumer Sciences, University Of Ghana Legon. \\ ${ }^{3}$ CSIR-Oil Palm Research Institute, box 74, Kade \\ *Corresponding Author: V. Y. Eziah: veziah@ug.edu.gh \\ Original submitted in on $4^{\text {th }}$ September 2014. Published online at www.m.elewa.org on 30th November 2014. \\ http://dx.doi.org/10.4314/jab.v83i1.12
}

\begin{abstract}
Background and Objective: The oil palm leaf miner Coelaenomenodera lameensis (Coleoptera: Chrysomelidae) is the most devastating insect pest of the African oil palm Elaeis guineensis Jacquin. Like most insect control programmes, control in Ghana has been through the use synthetic insecticides. The over-dependence on chemical control has brought in its wake adverse effects such as toxicity to the user and non-targeted organism. Entomopathogens have proven to be effective in the management of many insect species and these are environmentally-friendly. In this study we investigated reports by field workers of Council of Scientific and Industrial Research (CSIR)-Oil Palm Research Institute of Ghana who observed the presence of mycelia on the cuticle of cadavers of $C$. lameensis in their daily phytosanitary surveillance.

Methodology and Results: Field surveys were conducted in three oil palm plantations viz: CSIR-Oil Palm Research Institute and a commercial oil palm farm, both at Kusi in the Eastern Region, and Twifo Oil Palm Plantation of Unilever Ghana Limited at Twifo Praso in the Central Region of Ghana to collect cadaver of $C$. lameensis infected with fungi. The cadavers were aseptically cultured in the laboratory on Potato Dextrose Agar and fungi isolated and identified. A total of 17 fungal species were isolated from cadavers of the leaf miner. These include Aspergillus sp, Metarhizium sp, Paecilomyces sp, Penicillium sp, Pestalotia sp, Rhizoctonia sp, and three unidentified species. Bioassays conducted to ascertain the pathogenicity of the fungi against $C$. lameensis adult showed an overall mortality ranging between $12.5 \%-77.5 \%$ within 7 days. Growth of mycelia on treated dead insects ranged from $0 \%-47.5 \%$. The unidentified fungus coded BKFF was found to be the most lethal inducing about $77 \%$ mortality in the insect and thus more entomopathogenic, followed by Paecilomyces sp. (loprik31 and Pestalotia sp. (CKFF) (both 65\%) whilst Rhizoctonia sp was found to be the least lethal.

Conclusion and application of findings: This study presents important naturally occurring fungal species associated with the oil palm leaf miner $C$. lameensis in the field which famers can utilize as a control option upon further field studies.
\end{abstract}

Key words: Coelaenomenodera lameensis, entomopathogenic fungi, isolate, pathogenicity, mycelia 


\section{INTRODUCTION}

Oil palm is an economically important crop providing income for peasant farmers and foreign exchange for countries where they are found. According to Carrere (2006) world production of oil palm yielded 17.5 million tons of palm oil and 2.1 million tons of palm kernel oil in 1997 and almost doubled to 30 million tons by 2005. In 2001, there were 200,000 hectares of oil palm plantations in Thailand and this increased to 280,000 hectares by 2005 . A total area of three million hectares is covered by oil palm in Nigeria (Carrere, 2006). Malaysia and Indonesia, the world's leading producers of oil palm had a total of 4 million hectares and 5.3 million hectares covered by oil palm respectively in 2005. In Ghana, total land under the cultivation of oil palm has increased from 18,000 hectares in 1977 to 103,000 between 1970 and 1990 (Gyasi, 1992) and this has increased to about 304,000 hectares in 2002 (Carrere, 2006). The production of oil palm worldwide is increasing because palm oil is the world's best selling vegetable oil, representing $56 \%$ of the total global trade in edible oils (Carrere, 2006). Oil palm is high in oil content and has the highest potential of oil yield per acre when compared to other vegetable oils (Anyane, 1961). It is the only crop from which two kinds of oils can be obtained - palm oil and palm kernel oil. One major constraint to oil palm production is infestation by insect pests. The most important insect pest of the oil palm in West Africa is the oil palm leaf miner, Coelaenomenodera lameensis (Yawson, 2009). Damage is caused mostly by the larvae which mine the leaflets within which they live resulting in drying up of the fronds (Plates 1 and 2). The adults on the other hand cause a considerable damage only when their numbers exceed economic threshold of 1.5 adults per frond (Yawson et al., 2006). The adult feeds on the underside of the leaflets leading to partial drying up of the fronds. Heavy infestations can cause severe defoliation which can reduce seed production by 30 $50 \%$ (Lecoustre, 1998).

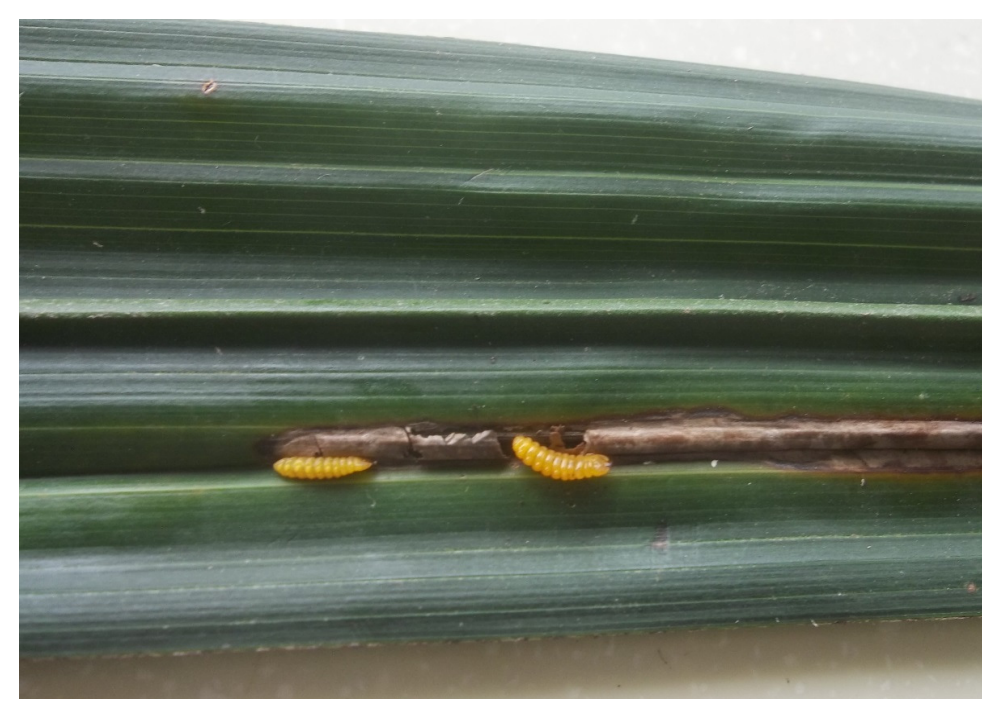

Plate 1. Larvae of C. lameensis on palm fronds 


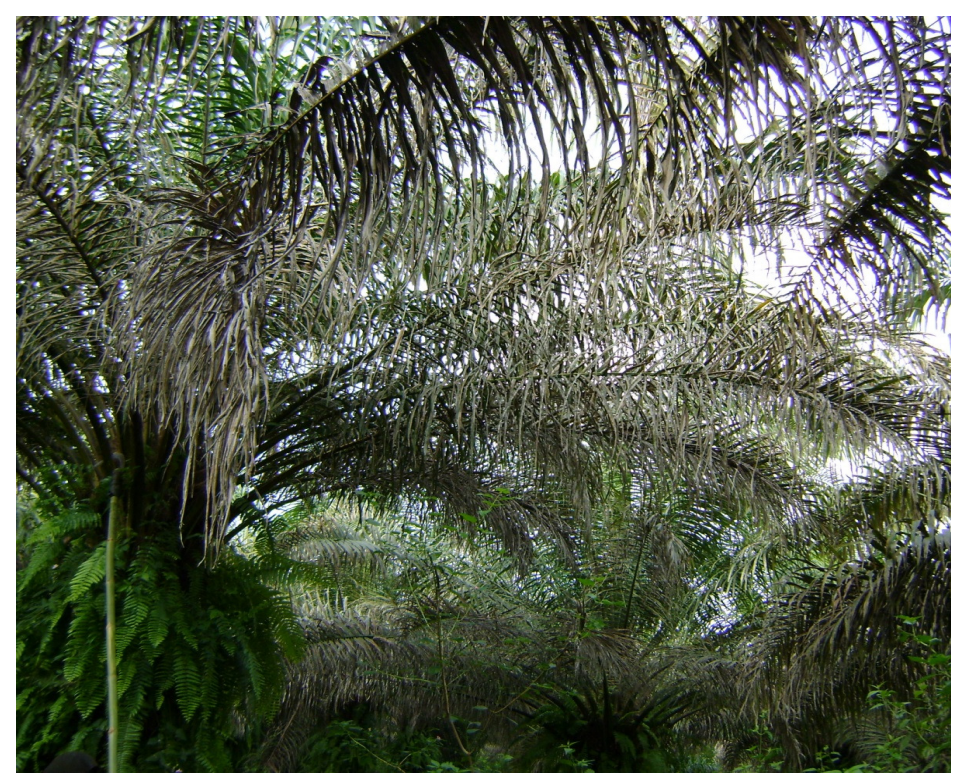

Plate 2. Damage caused to oil palm trees by C. lameensis

The control of $C$. lameensis has over the years been by synthetic insecticides through hot fogging, trunk injection, fluid air spraying, by phytosanitary surveillance, biological control and by planting resistant varieties of the oil palm. Currently, Evisect $S \&$ is the only preferred synthetic insecticide available for the control of adult $C$. lameensis in Ghana (Yawson, 2007). However, due to the incidence of development of resistance to synthetic insecticides by insects from prolonged use, the harmful effects of these chemicals on the environment, and residues in the fruits produced, it has become critical to develop other alternative control methods (Obeng-Ofori, D. 1998). The use of biological control appears to be environmentally friendly and safe in curbing incidence of insect pests. In the search for new avenues in biological control, the importance of entomopathogens has been highlighted as an environmentally-friendly pest control method (Paray and Rajabalee, 1997). According to Scholte et al., 2004, fungal diseases in

\section{MATERIALS AND METHODS}

Cadavers of $C$. lameensis were collected from three locations i.e. CSIR-OPRI plantation, a commercial oil palm farm both at Kusi in the Eastern Region and Twifo Oil Palm Plantation Ltd at Twifo Praso in the Central Region of Ghana. Cadavers collected were surface sterilized with $1 \%$ Sodium hypochloride and plated onto insects are common, widespread and can decimate pest populations in spectacular epizootics. Virtually all insect orders are susceptible to fungal diseases (Scholte et al., 2004). Large numbers of insect pathogenic organisms have been identified as possible biological control agents for grasshoppers (Bidochka and Khatchatourians, 1992). Commercial formulations of some entomopathogens such as Dipel 2x (Bacillus thuringiensis based-bio-product) have been made available for control of insect pests and these have proven to be efficient. At CSIR-OPRI field workers reported the presence of mycelia on cuticles of cadavers of $C$. lameensis during their daily phytosanitary surveillances suggesting that these fungal microbes may be exerting some control on the pest. Thus the search for these naturally occurring entomopathogens of the oil palm leaf miner became necessary. This study presents important naturally occurring fungal species associated with the oil palm leaf miner $\mathrm{C}$. lameensis in the field.

Potato Dextrose Agar (PDA) and this was observed for sporulation. The sporulated fungi were aseptically subcultured on PDA to obtain pure cultures. The various sporulated fungi were then coded based on the location of collection, mounted on slides and indentified using literature and identification keys (Smith, 1960; Barnett, 
1962; Poinar and Thomas, 1978; Humber, 2005). The occurrence of the various fungi collected from the farms was then calculated.

Bioassays: The spores of the various fungi were harvested and suspended in a conical flask containing 10 $\mathrm{mL}$ of sterile distilled water and $0.05 \%$ Tween $^{\circledR} 80$ solution. The concentrations of the spores of the various inocula prepared were determined by direct counting using the Improved Neubauer Haemocytometer ${ }^{\text {(Weber }}$ Scientific International Ltd, London). The spore concentration was adjusted to a $10^{7}$ conidia/mL for each isolated fungus and used in bioassays. A volume of $1 \mu \mathrm{L}$ of each inoculum was topically applied to the notum of each adult $C$. lameensis and placed in sterilized petri dishes and kept in controlled laboratory conditions of $27 \pm$

\section{RESULTS}

Isolated Fungi: Seventeen fungal species in all were isolated from the cadavers of $C$. lameensis and coded as Aoprik31, Boprik31, Coprik31, loprik31, Joprik31, Koprik31, Oprik31, Poprik31, Qoprik31, Roprik31, AKFF, BKFF, CKFF, DKFF, A/Twifo, B/Twifo and C/Twifo (Table 1). These were identified to include six Penicillium $2^{\circ} \mathrm{C}$ and $70 \pm 5 \%$ relative humidity. The control adult beetles were treated with sterilized distilled water containing $0.05 \%$ Tween ${ }^{\circledR} 80$. There were ten insects per treatment and replicated four times. Mortality counts were recorded every 24 hours for 7 days. Dead insects included those showing emergence of mycelia on the cuticle and those which failed to respond when prodded with a blunt probe. Dead insect showing emergence of mycelia were then transferred aseptically onto PDA and incubated at $27 \pm 2^{\circ} \mathrm{C}$ for 7-10 days. Sporulating fungi were re-isolated and re-identified.

Data analysis: The incidence of the various fungi was presented in a pie chart. Mortality data was subjected to Analysis of Variance (ANOVA) and means separated using Duncan Multiple Range Test (DMRT).

species (35\%), three Pestalotia species (17\%), two Rhizoctonia species (12\%), one Aspergillus species, one Metarhizium species, one Paecilomyces species (both $5 \%)$ and three other unidentified species (18\%) (Figure 1).

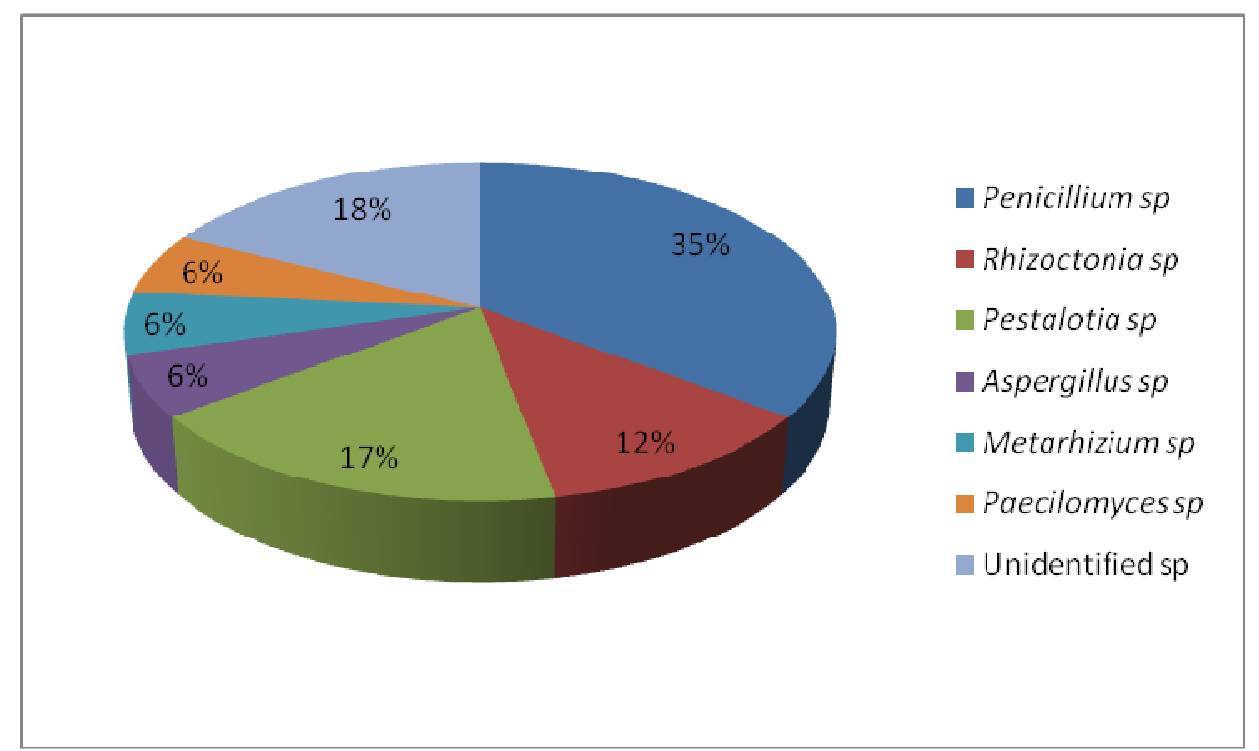

Figure 1: Incidence (\%) of fungi isolated from cadavers of $C$. lameensis collected from the study 
Table 1: Identification and characteristics of fungi isolated from cadavers of $C$. lameensis

\begin{tabular}{|c|c|c|c|c|c|}
\hline Isolate & Growth morphology & Colony colour & Key characteristics & Spore shape & Identity \\
\hline Aoprik31 & Cushion-like & $\begin{array}{l}\text { White with acervuli } \\
\text { dark }\end{array}$ & $\begin{array}{l}\text { Conidia with 3-5 septa, dark at } \\
\text { the median but colourless at the } \\
\text { terminal end with two or more } \\
\text { hyaline apical appendages }\end{array}$ & $\begin{array}{l}\text { Fusoid with hyaline } \\
\text { pointed end cells }\end{array}$ & Pestalotia sp. \\
\hline Boprik31 & $\begin{array}{l}\text { Fast growing and } \\
\text { fluffy }\end{array}$ & Gray & Threads of mycelia & Lacking & Rhizoctonia sp \\
\hline Coprik31 & $\begin{array}{c}\text { Concentric growth } \\
\text { rings }\end{array}$ & Olive green & Phialides are penicillate & Globose & Penicillium sp \\
\hline loprik31 & Cotton like & White & $\begin{array}{l}\text { Ropes of hyphae and various } \\
\text { types of spore-bearing structures }\end{array}$ & Elliptical & Paecilomyces sp \\
\hline Joprik31 & $\begin{array}{l}\text { Dense and upright } \\
\text { conidia. }\end{array}$ & Dark brown & $\begin{array}{l}\text { Conidiophores ends in clavate } \\
\text { swelling with phialides at the } \\
\text { apex }\end{array}$ & Globose & Aspergillus sp. \\
\hline Koprik31 & $\begin{array}{l}\text { Powdery and grows } \\
\text { in scattered colonies }\end{array}$ & Violet & Phialides are penicillate & Globose & Penicillium sp. \\
\hline Oprik31 & $\begin{array}{l}\text { Concentric growth } \\
\text { and fluffy }\end{array}$ & Gray and white & Threads of mycelia & Lacking & Rhizoctonia sp \\
\hline Poprik31 & Slow growing & $\begin{array}{l}\text { White with yellow } \\
\text { background }\end{array}$ & & & Unidentified \\
\hline
\end{tabular}


Table 1: Contd. Identification and characteristics of fungi isolated from cadavers of $C$. lameensis

\begin{tabular}{|c|c|c|c|c|c|}
\hline Isolate & Growth morphology & Colony colour & Key characters & Spore shape & Identity \\
\hline Qoprik31 & Concentric growth & $\begin{array}{l}\text { White with small black } \\
\text { acervuli pustules }\end{array}$ & $\begin{array}{l}\text { Conidia with 3-5 septa, dark } \\
\text { at the median but colourless } \\
\text { at the terminal end with two or } \\
\text { more hyaline apical } \\
\text { appendages }\end{array}$ & $\begin{array}{l}\text { Fusoid with hyaline } \\
\text { pointed end cells }\end{array}$ & Pestalotia sp \\
\hline Roprik31 & Powdery & $\begin{array}{l}\text { Gray with tangerine } \\
\text { background }\end{array}$ & Phialides are penicillate & Globose & Penicillium sp \\
\hline AKFF & Powdery & Olive green & Phialides are penicillate & Globose & Penicillium sp \\
\hline BKFF & Slow growing and dense & Snowy White & & & Unidentified \\
\hline CKFF & $\begin{array}{l}\text { Dense growth and } \\
\text { cushion like }\end{array}$ & $\begin{array}{l}\text { Snowy White with } \\
\text { acervuli dark }\end{array}$ & $\begin{array}{c}\text { Conidia with } 3-5 \text { septa, dark } \\
\text { at the median but colourless } \\
\text { at the terminal end with two } \\
\text { or more hyaline apical } \\
\text { appendages }\end{array}$ & $\begin{array}{l}\text { Fusoid, with hyaline } \\
\text { pointed end cells }\end{array}$ & Pestalotia sp \\
\hline DKFF & Slow growing & Snowy white & & & Unidentified \\
\hline A/Twifo & $\begin{array}{l}\text { Fluffy, cotton-like and } \\
\text { dense }\end{array}$ & White & $\begin{array}{l}\text { Conidiophores erect and } \\
\text { closely grouped }\end{array}$ & Ovoid & Metarhizium sp \\
\hline B/Twifo & Powdery & Olive green & Phialides are penicillate & Globose & Penicillium sp \\
\hline C/Twifo & $\begin{array}{c}\text { Concentric growth and } \\
\text { powdery }\end{array}$ & Olive green & $\begin{array}{c}\text { Penicillate phialides and } \\
\text { pinch off conidia in dry } \\
\text { chains }\end{array}$ & Globose & Penicillium sp \\
\hline
\end{tabular}


Pathogenicity test: The fungal isolates induced varying levels of mortality in adult $\mathrm{C}$. lameensis (Table 2). One unidentified isolate BKFF collected from a commercial farmer's field at Kusi induced the highest mortality of 77.5 $\%$ at spore concentration of $3.3 \times 10^{7}$ conidia/mL while Rhizoctonia sp (Oprik31) induced the lowest mortality
(12.5\%) within seven days of inoculation. However, Rhizoctonia sp lacked spores and therefore the spore concentration could not be determined. Also, Paecilomyces sp (loprik31) and Pestalotia sp (CKFF) induced high mortality $(65 \%)$ in the adult insects after seven days of treatment.

Table 2: Mortalities and conidia emergence post mortem of adult $C$. lameensis seven days after inoculation with the various isolated fungi

\begin{tabular}{l|c|c|c}
\hline Fungal Isolates & $\begin{array}{c}\text { Spore } \\
\text { concentration }\end{array}$ & $\begin{array}{c}\text { Mean mortalities seven days } \\
\text { after inoculation ( } \mathbf{S E} \text { ) }\end{array}$ & $\begin{array}{c}\text { Growth of mycelia upon } \\
\text { death of insect (\%) }\end{array}$ \\
\hline Rhizoctonia sp. (Oprik31) & 0.00 & $12.5 \pm 0.75 \mathrm{a}$ & 0 \\
Aspergillius sp. (Joprik31) & $2.30 \times 10^{7}$ & $17.5 \pm 1.12 \mathrm{a}$ & 2.5 \\
Penicillium sp. (BTwifo) & $2.10 \times 10^{7}$ & $15.0 \pm 0.29 \mathrm{a}$ & 2.5 \\
Rhizoctonia sp. (Boprik31) & 0.00 & $15.0 \pm 0.29 \mathrm{a}$ & 0 \\
Control & 0.00 & $16.8 \pm 0.58 \mathrm{a}$ & 0 \\
Penicillium sp. (Roprik31) & $1.20 \times 10^{7}$ & $17.5 \pm 0.63 \mathrm{a}$ & 0 \\
Penicillium sp. (Coprik31) & $1.70 \times 10^{7}$ & $20.0 \pm 0.71 \mathrm{a}$ & 2.5 \\
Poprik31 (unidentified) & $1.10 \times 10^{7}$ & $15.0 \pm 0.29 \mathrm{ab}$ & 0 \\
Penicillium sp. (Koprik31) & $5.47 \times 10^{7}$ & $25.0 \pm 0.50 \mathrm{ab}$ & 17.5 \\
DKFF (unidentified) & $0.79 \times 10^{7}$ & $27.5 \pm 0.75 \mathrm{ab}$ & 7.5 \\
Penicillium sp. (CTwifo) & $1.60 \times 10^{7}$ & $27.5 \pm 0.48 \mathrm{ab}$ & 2.5 \\
Pestalotia sp. (Aoprik31) & $2.10 \times 10^{7}$ & $32.5 \pm 1.18 \mathrm{ab}$ & 0 \\
Penicillium sp. (AKFF) & $1.41 \times 10^{7}$ & $35.0 \pm 1.32 \mathrm{abc}$ & 0 \\
Pestalotia sp. (Qoprik31) & $3.50 \times 106$ & $37.5 \pm 1.80 \mathrm{abc}$ & 0 \\
Metarhizium sp. (ATwifo) & $2.80 \times 107$ & $52.5 \pm 0.75 \mathrm{bcd}$ & 0 \\
Paecilomyces sp. (loprik31) & $2.70 \times 10^{7}$ & $65.0 \pm 0.65 \mathrm{~cd}$ & 15 \\
Pestalotia sp. (CKFF) & $8.50 \times 10^{6}$ & $65.0 \pm 0.65 \mathrm{~cd}$ & 0 \\
BKFF (unidentified) & $3.30 \times 10^{7}$ & $77.5 \pm 0.25 \mathrm{~d}$ & 47.5 \\
\hline
\end{tabular}

Mean mortalities \pm SE followed by same letters in same columns are not significantly different at $p<0.05$ from one another (Duncan's multiple test).

Re-isolation of fungi from treated insects: Inoculated insects after death showed different incidence of sporulation and re-isolation confirmed them to be same organisms that were used in inoculation (Figure 2). A $47.5 \%$ growth of mycelia was observed for the unidentified (BKFF) fungus and no growth of mycelia was observed for Pestalotia sp, Rhizoctonia sp, Metarhizium sp, Poprik31 (unidentified) and Penicillium sp. (Roprik31, AKFF and Doprik31). 


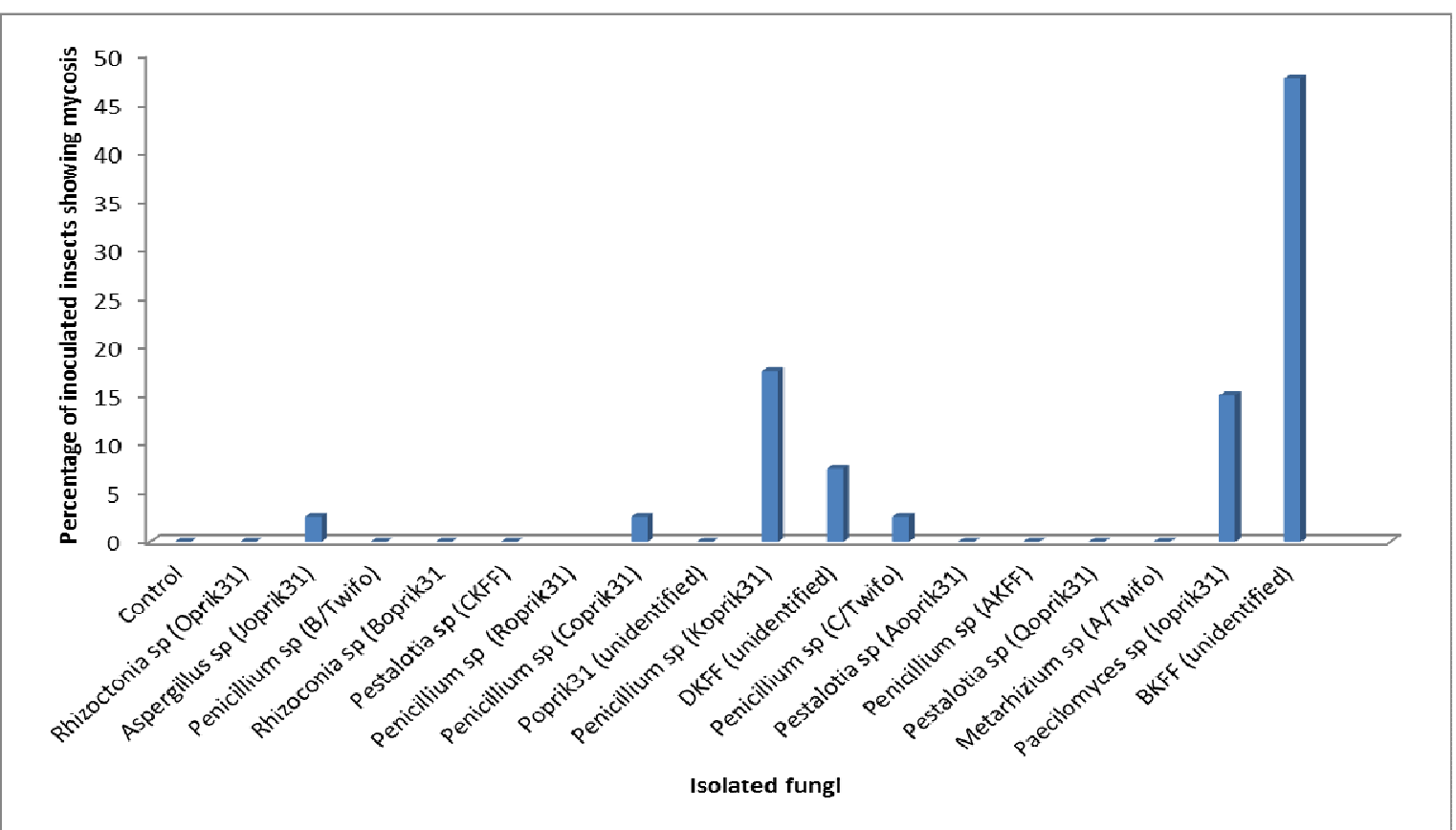

Figure 2: Emergence of mycelia post mortem of adult insect which were inoculated with isolated fungi.

\section{DISCUSSION}

The use of Entomopathogenic fungi as alternative to synthetic insecticides is receiving renewed interest (McCoy, 1990). They have been found to be potentially the most versatile entomopathogens because many have wide host ranges and infect different stages and ages of their host, causing natural epizootics (Ferron, 1981). These fungi include Paecilomyces farinosus, Zoopthora radicans, (Bredfeld) Batko (Zygomycetes: Entomophorales), Beauveria bassiana, (Balsamo) Vuillemin (Deuteromycetes), B. brogniati, $P$. fumosoroseus and Metarhizium anisopliae among others (Sairbanu and Rabindra, 2002). In the current study seventeen fungal species were isolated from cadavers of C. lameensis suggesting that fungal pathogens are common microbial agents in regulating field populations of $C$. lameensis. This confirms report by Amer et al. (2008) that fungal infections are common in the Coleopterans. The fungi isolated in this study belonged to two genera i.e. Ascomycotina (Penicillium sp, Aspergillus $\mathrm{sp}$, Pestalotia sp, Metarhizium sp and Paecilomyces sp) and Basidiomycotina (Rhizoctonia sp.), thus confirming reports by (Talwar, 2005; Dolinski and Lacey, 2007) that most entomopathogenic fungi are in the phylum Ascomycotina and Basidiomycotina. Pathogenicity screening tests showed that all the isolated fungi induced varying degrees of mortality in adult $C$. lameensis. The highest mortality $(77.5 \%)$ induced by the unidentified fungus coded BKFF (from commercial farmer's farm) seven days after inoculation suggests that the spores are lethal to C. lameensis. A $47.5 \%$ emergence of mycelia upon death of beetles further suggests that it has a great potential as a bio-control agent as it can self-perpetuate once the inoculum is introduced into field populations of C. lameensis. Paecilomyces $\mathrm{sp}$ also induced a high mortality of $65 \%$ and growth of mycelia (15\%) after death of treated insects suggests that the fungus could serves as potential agent against $\mathrm{C}$. lameensis. Paecilomyces sp has been found to be pathogenic to many insects (Alves et al., 2004; Amer et al., 2008; Er et al., 2008; Sookar et al., 2008). Jiji et al. (2006) also reported more than $50 \%$ cumulative mortality when puparia and adults Bactocera curcubitae were inoculated with Paecilomyces lilacinus. Paecilomyces sp has been isolated from white grubs, Coccinella septempunctata, Galleria mollenella and Bactocera cucurbitae (Lezama-Gutiérrez et al., 2000; Er et al. 2008; Ceryngier, 2000; Jiji et al., 2006). Paecilomyces ferinosus has been reported to be very virulent against all immature stages of the diamondback moth (DBM) except the egg and mortality occurs 48-72 hours after exposure of the pest to the fungal inoculum (Gopalakrishnan et al., 2000) . Penicillium sp, the most prevalent fungus and Aspergillus sp isolated have been reported by Er et al. (2008) as common saprophytic fungi that invades cadavers of insects. The authors also reported that fungal growths noticed on most of the cadavers of Coccinellids they worked with were generally 
those of the saprophytic fungus Penicillium. These genera of fungi have been isolated from field populations of diamondback moth in Ghana (Anaisie et al., 2011) and Zonocerus variegatus in Ibadan (Balogun and Fagade, 2004). However in the present study, these two genera may have contributed to the mortality of adult $C$. lameensis as they were re-isolated from treated insects and identified as such. Metarhizium sp have been isolated from many insects and much work has been done on their efficacy and safety. The genus is the very first entomopathogenic fungus that was mass produced and used as pests control agent and commercial formulations of the bio-pesticides are available under many patent names (deFaria and Wraight, 2007). Metarhizium sp (ATwifo) and Pestalotia sp isolated in the present study each induced mortalities above $50 \%$ but doesn't attest to be the causative organism when a reisolation test was conducted. However, Liu et al. (1996) observed that $M$. anisopliae var. anisopliae can induce up to $90 \%$ mortality in the larvae of the diamondback moth within 3 days. Penicillium sp were isolated from all three farms surveyed. The overall cumulative mortalities induced by the various Penicillium sp isolated were between $15 \%$ and $35 \%$. However, sporulation tests conducted on dead beetles revealed quite high recovery rate of (17.5\%), in the Koprik 31 strain, and low recovery of $2.5 \%$ and $0 \%$ suggesting that all the species collected may not be important microbial control agents of $C$. lameensis. This confirming report by Humber (2005) that Penicillium sp may be a primary pathogen, facultative pathogen or just contaminant saprobes. Aspergillus $\mathrm{sp}$ also induced a low mortality of $17.5 \%$ but the fungus was recovered at $2.5 \%$ upon re-isolation. However, Baidoo and Ackuaku (2011) recorded a high mortality of $86.6 \%$

\section{ACKNOWLEDGEMENT}

The authors wish to express their sincere thanks to the Director of Counsil for Scientific and Industrial Research (CSIR) -Oil Palm Research Institute (OPRI), Ghana for providing the resources and facilities for the investigation. Many thanks go to the technicians of the Entomology

\section{REFERENCES}

Alves, S. B., Rossi, L. S., Walder, J. M. M., Vieira, S. A. 2004. Evaluation of entomopathogenic fungus against Ceratitis capitata. Manejo Integrado de Plagas y Agroecología, 72: 31-38.

Amer, M. M., El-Sayed, T. E., Bakheit, H. K., Moustafa, S. A., El-Sayed, Y. A. 2008. Pathogenicity and Genetic Variability of five entomopathogenic fungi against Spodoptera littoralis. Research when $2^{\text {nd }}$ stage larvae of the maize stem borer (Eldana saccharina) were inoculated with Aspergillus flavus. Rhizoctonia sp and Pestalotia sp seems not to have been isolated from any insect. However, Elliot (2005) has reported that Pestalotia species is a pest on many palm species. This could probably explain why it was found on cadaver of the beetles. Ivanovic and Ivanovic, (2001) and Vico et al. (2005) have also reported Pestalotia sp as a plant pathogen of potato, beans, alfalfa, tomato, cabbage and ornamentals. Rhizoctonia sp. on the other hand induced the lowest mortality of $12.5 \%$ suggesting that it may not be an entomopathogen but perhaps a saprophytic fungus that invaded the cadaver after death. Furthermore, a $0 \%$ mycosis on inoculated insects upon death suggests that it may not be important in controlling C. lameensis. The isolates BKFF, DKFF (from a commercial farm at Kusi), and Ploprik31 (from CSIROPRI plantation) appear from macroscopic and microscopic characteristics to be the same organism. Identification of these fungi were however not possible because the reproductive structures could not be clearly seen under the microscope and requires further studies. This study shows that some fungi are associated with the oil palm leaf miner, C. lameensis in nature, some of which are entomopathogens. Efficacy under laboratory conditions demonstrated the ability of these fungal isolates to induce some levels of mortalities in C. lameensis and may be useful bio-control agents against C. lameensis. The most promising isolates were the unidentified fungi (BKFF) and Paecilomyces sp whilst Rhizoctonia sp was found to be the least lethal. Further field tests are required on the important species identified in this study for possible incorporation into integrated control of $C$. lameensis.

Laboratory of CSIR-OPRI for their immense assistance. Also many thanks go to the Staff of Pathology Laboratory of Crop Science Department of the University of Ghana. The project topic is from CSIR-OPRI.

Journal of Agriculture and Biological Science, 4(5): 354-367.

Anaisie, P. E., Eziah, V. Y., Owusu, E. O. 2011. The potential of indigenous entomopathogenic fungi for the management of the diamond back moth, Plutella xylostella L. (Lepidoptera: Yponomeutidae) in Ghana. International 
Research Journal of Biochemistry and Bioinformatics, 1(10): 275-281.

Anyani, S.L. 1961. The oil palm belts of Ghana. Ghana Bulletin of Agricultural Economics, 1(1):1- 43.

Baidoo, P. K., and Ackuaku, S. K. 2011. The effects of spore concentration of entomopathogenic fungi on larval mortality and development of the maize stem borer, Eldana saccharina (Lepidoptera: Pyralidae). Journal of Applied Biosciences, 47: 3221-3229.

Balogun, S. A., and Fagade, O. E. 2004. Entomopathogenic fungi in populations of Zonocerus variegatus (I) in Ibadan, Southwest, Nigeria. African Journal of Biotechnology, 3(8): 382-386.

Barnett, H. L. 1962. Illustrated Genera of Imperfect fungi (2nd Ed.). Burgess Publishing Company, Minneapolis.

Bidochka, M. J. and Khatchatourians, G. G. 1992. Microbial and Protozoan Pathogens of Grasshoppers and Locusts as Potential Biocontrol Agents. Biocontrol Science and Technology, 1: 243-249.

Carrere, R. 2006. Oil Palm. From cosmetics to Biodiesel. Colonization lives on. World Rianforest Movement. International secretariat. Maldonado, Uruguay.

Ceryngier, P. 2000. Overwintering of Coccinella septempuntata (Coleoptera: Coccinellidae) at different altitudes in the Karkonosze Mts, SW Poland. European Journal of Entomology, 97: 323-328.

de Faria, M. R., and Wraight, S. P. 2007. Mycoinsecticides and mycoacaricides: A comprehensive list with worldwide coverage and internal classification of formulation types. Biological Control, 43: 237-256.

Dolinski, C., and Lacey, L. A. 2007. Microbial control of arthropod pests of tropical tree fruits. Neotropical Entomology, 36 (2): 161-179

Elliot, M. L. 2005. Pestalotiopsis (Pestalotia) Diseases of palm. A series of the plant pathology Department. Florida cooperative extension service, Institute of food and agricultural sciences, University of Florida. 218 PP

Er, M. K., Tunaz, H., Isikber, A. A., Satar, S., Mart, C., Uygun, N. 2008. Pathogenicity ofEntomopathogenic fungi to Ceccinella septempunctata L. (Coleoptera: Coccinellidae) and a survey of fungal diseases of Coccinellids.
King Saud University Journal of Science and Engineering, 11(1): 118-122.

Ferron, P.1981. Pest control by the fungi Beauveria and Metarhizium. In Burges HD (editor), Microbial control of pest and plant diseases, pp 465-482. Academic Press, London

Gopalakrishnan, C., Anusuya, D., Narayanan, K. 2000. Susceptibility of Plutella xylostella to the entomopathogenic fungus Paecilomyces farinosus. Indian Journal of Agricultural Science, 70, 341-343

Gyasi, E.A. 1992. Emergence of new oil palm belt in Ghana. Tijdschrift voor economische en sociale geagrafie, 83:34-49.

Humber, R. A. 2005. Entomopathogenic Fungal Identification. Originally prepared for a Las Vegas, Nevada- $7^{\text {th }}$ November, 1998. USA.

Ivanovic, M., and Ivanovic, D. 2001. Mikoze I pseudomikoze biljaka. Univerzitet u Beodradu, Poljoprivredni fakultet, Beograd, Serbia.

Jiji, T., Praveena, R., Babu, K., Naseema, A., Anitha N. 2006. Three promising fungal strains pathogenic to fruit flies. Proceedings of the $7^{\text {th }}$ International symposium on fruit flies of Economic importance. 10 th $-15^{\text {th }}$ September, 2006 at Salavador, Brazil, 175-177 PP

Lecouster, R. (1998). Approche mathématique d'un équilibre à Coelaenomenodera minuta Uhmann et de ses parasites d'œufs. Thèse de Doctorat. Institut des sciences et Techniques du Languedoc. pp 289.

Lezama-Gutiérrez, R., Hamm, J. J., Ochoa-Molina, J., Lopez-Edwards, M., Pescador-Rubio, A., González-Ramirez, M., Styer, E. L. 2000. Occurrence of entomopathogens of Spodoptera frugiperda (Lepidoptera: Noctuidae) in the Mexican State of Michoácan Colima, Jalisco and Tamaulipas. Florida Entomologist, 84(1): 23-30.

Liu, S., S. D. Liu and G. Grey 1996. The application of fungicide resistant entomopathogenic green muscardine fungus in Taiwan: biological control of coconut leaf beetle (Brontispa: longissima) and diamondback moth (Plutella xylostella). Biological Pest Control in Systems of Integrated Pest Management. Proceedings of the International Symposium on The use of Biological Control Agents under Integrated Pest Management, 154-163 PP

McCoy, C. W. 1990. Entomopathogenic fungi as microbial pesticides. In: New Directions in Biological Control. Alternatives for suppressing 
Agricultural Pests and Diseases (Baker, R. R. and Durin, P. E. ed.), Alan R. Liss, New York, 139-159 PP.

Obeng-Ofori, D. 1998. Pests of field, plantation and vegetable crops. The biology, damage and control. Dept. of Crop Science, University of Ghana, Legon. $151 \mathrm{pp}$.

Paray, N. B., and Rajabalee, A. 1997. Preliminary studies on entomopathogens associated with sugar cane pests in Mauritius. Journal of American Medical Association, 19:15-20.

Poinar, G. O., \& Thomas, G. M. 1978. Diagnostic Manual for the Identification of Insect Pathogens. Plenum Press, New York.

Sairbanu, B. and R. J. Rabindra 2002. Effect of entomofungal pathogens after in vivo passage through the larvae of diamondback moth, Plutella xylostella L. (Lepidoptera: Yponomeutidae). Symposium on the Biological Control of Insect Pests. pp 141-148. Entomological Research Institute, Chennai, Feb. 7-8.

Scholte, E-J., Knols, B. G. J., Samson, R. A., Takken, W. 2004. Entomopathogenic fungi for mosquito control: A review. Journal of Insect Science, 4(19): 24.

Smith, G. 1960. An Introduction to Industrial Mycology. Edward Arnold Publishers Ltd, London.

Sookar, P., Bhagwant, S., and Ouna, A. E. 2008. Isolation of entomopathogenic fungi from the soil and their pathogenicity of two fruit fly species (Diptera: Tephritidae). Journal of Applied Entomology, 132: 778-788.

Talwar, B.H. 2005. Isolation and Characterisation of Entomopathogenic fungi and their effectiveness. Unpublished PhD Dissertation, University of Agricultural Sciences, Dharwad.

Vico, I., Krstić, B., Bulajić, A., Dukić, N. 2005. Viŝjedarna Rhizoctonia sp-patogen hrizanteme. Pesticidi i fitomedicina, Privredni pregled. Beograd, Serbia.

Yawson, G.K., Appiah, S.O., Kim, C-Sa., Owusu, E.O. 2006. Evaluation of monitoring surveillance of oil palm leaf miner Coelaenomenodera lameensis Berti and Mariau (Coleoptera: Chrysomelidae) live indices trend and control. Journal of the Ghana Science Association, 8(1):118-126.

Yawson, G.K. 2007. Studies on some major insect pests of coconut (Cocos nucifera $\mathrm{L}$ ) oil palm (Elaeis guineensis Jacq.), and their management in Ghana. (Ph.D Thesis. United Graduate School of Agriculture Sciences. Ehime University Japan)

Yawson, G.K. 2009. management and control of the oil palm leaf miner Coelaenomenodera lameensis Berti and Mariau (Coleoptera: Chrysomelidae). A case study in Kade, Ghana. Technical report, Council for Scientific and Industrial ResearchOil Palm Research Institute. CSIROPRI/TR/GKY/2009/28. 